\title{
Paracoccus isoporae sp. nov., isolated from the reef-building coral Isopora palifera
}

\author{
Ming-Hui Chen, ${ }^{1}$ Shih-Yi Sheu, ${ }^{2}$ Chaolun Allen Chen, ${ }^{3}$ Jih-Terng Wang ${ }^{4}$ \\ and Wen-Ming Chen ${ }^{1}$
}

Correspondence
Wen-Ming Chen
p62365@ms28.hinet.net

The genus Paracoccus, first proposed by Davis et al. (1969), belongs to the family Rhodobacteraceae of the order Rhodobacterales in the class Alphaproteobacteria of the phylum Proteobacteria. At the time of writing, the genus Paracoccus comprised 30 recognized species. Members of the genus Paracoccus are metabolically versatile and are widely distributed, having been isolated from a variety of different environments, including soil (Siller et al., 1996; Tsubokura et al., 1999), a bioreactor (La et al., 2005), activated sludge (Liu et al., 2006), root nodules (Deng et al., 2010), cornetfish (Kim et al., 2010) and the marine environment (Berry et al., 2003; Kim et al.,

Abbreviations: DPG, diphosphatidylglycerol; PC, phosphatidylcholine; $P G$, phosphatidylglycerol.

The GenBank/EMBL/DDBJ accession number for the 16S rRNA gene sequence of strain $\mathrm{SW}^{-3^{\top}}$ is FJ593906.

One supplementary figure and one supplementary table are available with the online version of this paper.
2006). In addition to this, at least one species of the genus Paracoccus has been identified as an occasional pathogen of humans (Daneshvar et al., 2003; Wallet et al., 2010). The aim of the present study was to determine the taxonomic position of a Paracoccus-like isolate, designated strain $\mathrm{SW}-3^{\mathrm{T}}$, which was isolated from the reef-building coral Isopora palifera, collected off the coast of Southern Taiwan.

A $50 \mathrm{~g}$ sample of coral was collected in a sterile bag from the Kenting coast, Pingtung County, Southern Taiwan $\left(21^{\circ}\right.$ $56^{\prime} 29^{\prime \prime} \mathrm{N} 120^{\circ} 44^{\prime} 70^{\prime \prime} \mathrm{E}$ ), at a depth of 3-8 $\mathrm{m}$, stored at $4{ }^{\circ} \mathrm{C}$ and transported to the laboratory within $3-4 \mathrm{~h}$. The coral sample was ground and plated on marine agar 2216 (MA; BD Difco) by using a standard dilution plating method. After incubation of the plates at $25{ }^{\circ} \mathrm{C}$ for 5 days, a pure culture of strain SW $-3^{\mathrm{T}}$ was obtained from a single colony. The strain was preserved at $-80{ }^{\circ} \mathrm{C}$ in a suspension containing $20 \%(\mathrm{v} / \mathrm{v})$ glycerol in marine broth 2216 (MB; BD Difco) or by lyophilization with $20 \%$ (w/v) skimmed 
milk. Five type strains, Paracoccus zeaxanthinifaciens JCM $21774^{\mathrm{T}}$, Paracoccus aestuarii JCM $15119^{\mathrm{T}}$, Paracoccus marinus NBRC $100637^{\mathrm{T}}$, Paracoccus homiensis KACC $11518^{\mathrm{T}}$ and Paracoccus denitrificans BCRC $12285^{\mathrm{T}}$, were obtained from their respective culture collections and used as reference strains for phenotypic and genotypic tests.

The bacterial cells were observed by phase-contrast microscopy (DM 2000; Leica) in the lag, exponential and stationary phases of growth to ascertain their morphology. Cell motility was tested by using the hanging-drop and semi-solid agar methods. Spot Test Flagella Stain (BD Difco) was used for flagellum staining. The Gram Stain Set $\mathrm{S}$ kit (BD Difco) and Ryu non-staining $\mathrm{KOH}$ method (Powers, 1995) were used to test the Gram reaction. Poly$\beta$-hydroxybutyrate granule accumulation was observed under light microscopy after staining of the cells with Sudan Black. Colony morphology was examined using a stereoscopic microscope (SMZ 800; Nikon). The optimum $\mathrm{pH}$ range for growth was examined in $\mathrm{MB}$ using glycine/ $\mathrm{HCl}$, citrate $/ \mathrm{Na}_{2} \mathrm{HPO}_{4}$, phosphate or glycine/ $\mathrm{NaOH}$ buffers to adjust the media to $\mathrm{pH} 3-4,4-8,6-8$ or $9-11$, respectively, in $\mathrm{pH}$ unit intervals of 1 . The $\mathrm{pH}$ was adjusted prior to sterilization and post-sterilization tests revealed only minor changes in the $\mathrm{pH}$. Tolerance to $0,0.5,1,2,3,4$ and $5 \%(\mathrm{w} / \mathrm{v}) \mathrm{NaCl}$ was tested on $\mathrm{NaCl}-$ free $\mathrm{MB}$, prepared according to the formula of the BD Difco medium, with the $\mathrm{NaCl}$ concentration altered as required. Cell growth was measured at $4-45{ }^{\circ} \mathrm{C}$ in MB. For all tests, growth was determined by measuring the turbidity $\left(\mathrm{OD}_{600}\right)$ of the cultures. Anaerobic cultivation was performed on MA using the Oxoid AnaeroGen system.

Extraction of genomic DNA, PCR amplification and sequencing of the $16 \mathrm{~S}$ rRNA gene were carried out as previously described (Chen et al., 2001). The 16S rRNA gene sequence of strain SW $-3^{\mathrm{T}}$ was obtained using a DNA sequencer (ABI Prism 310; Applied Biosystems). The almost-complete $16 \mathrm{~S}$ rRNA gene sequence (1426 nt) of strain SW $-3^{\mathrm{T}}$ was compared against those of related species available from the EzTaxon server (Chun et al., 2007), the Ribosomal Database Project (Maidak et al., 2001) and the GenBank database (http://blast.ncbi.nlm.nih.gov/Blast.cgi). After multiple alignments of the data were performed in CLUSTAL_X (Thompson et al., 1997), analysis of the sequence data was performed by using the software package BioEdit (Hall, 1999) and MEGA version 3.1 (Kumar et al., 2004). Distances, corrected according to Kimura's two-parameter model (Kimura, 1983), were calculated and clustering was performed using the neighbour-joining method (Saitou \& Nei, 1987). Maximum-likelihood (Felsenstein, 1981) and maximum-parsimony (Kluge \& Farris, 1969) trees were also reconstructed by using the treeing algorithms in the PHYLIP software package (Felsenstein, 1993). In each case, bootstrap values were calculated based on 1000 replications. A comparison of the 16S rRNA gene sequence of strain SW$3^{T}$ with those of members of genera of the order Rhodobacterales in the class Alphaproteobacteria showed that the strain fell within the radiation occupied by the genus Paracoccus (Fig. 1). In the phylogenetic tree based on the neighbour-joining algorithm, strain $S W-3^{T}$ formed a coherent clade with species of the genus Paracoccus. A similar topology was obtained in phylogenetic trees reconstructed using the maximum-parsimony and maximum-likelihood algorithms (Fig. 1). According to pairwise sequence comparisons, strain $\mathrm{SW}-3^{\mathrm{T}}$ was most closely related to $P$. aestuarii $\mathrm{B}^{\mathrm{T}}$ (96.8\% $16 \mathrm{~S}$ rRNA gene sequence similarity), P. homiensis DD-R11 ${ }^{\mathrm{T}}(96.6 \%)$, P. marinus $\operatorname{KKL}^{-A 5}{ }^{\mathrm{T}}(96.1 \%)$, P. denitrificans DSM $413^{\mathrm{T}}(95.8 \%)$ and

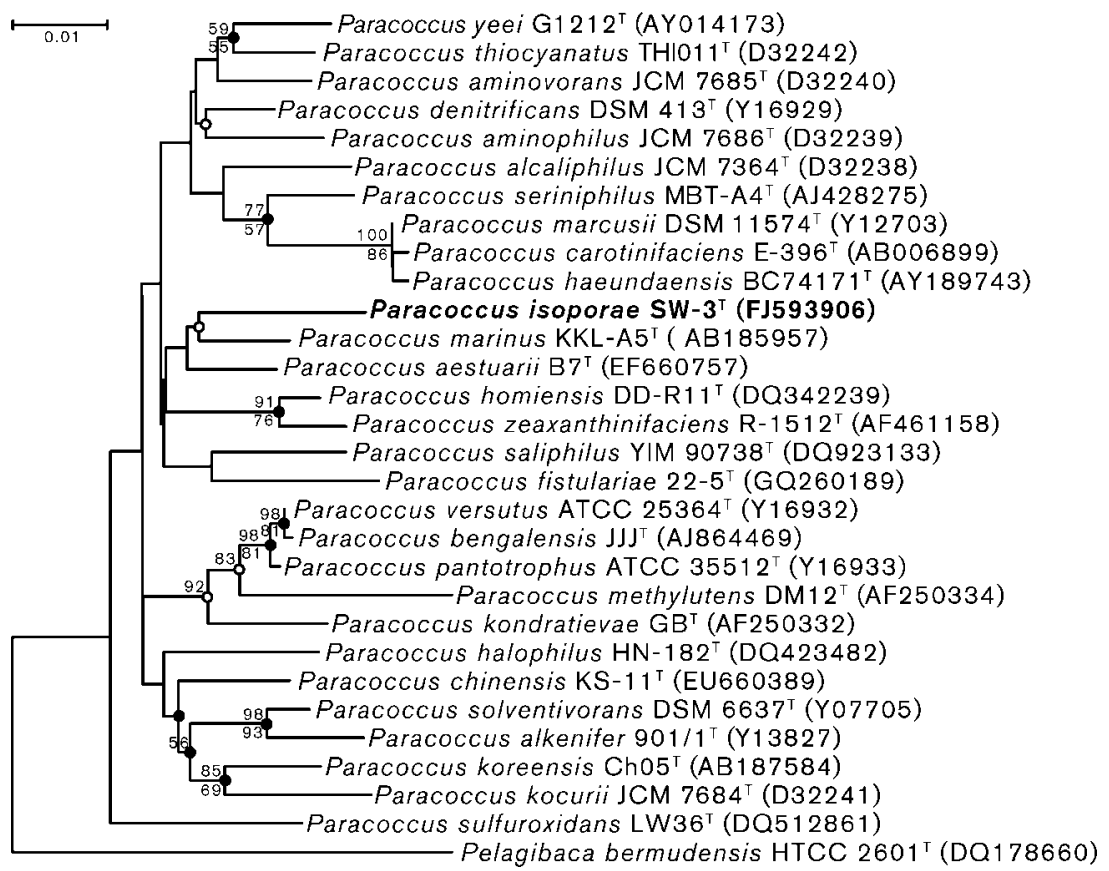

Fig. 1. Neighbour-joining phylogenetic tree based on 16S rRNA gene sequences showing the position of strain $S W-3^{\top}$ and closely related species of the genus Paracoccus. Numbers at nodes are bootstrap percentages $(>50 \%)$ based on the neighbour-joining (above nodes) and maximum-parsimony (below nodes) tree-making algorithms. Filled circles indicate branches of the tree that were also recovered using the maximum-likelihood and maximum-parsimony tree-making algorithms. Open circles indicate that the corresponding nodes were also recovered in the tree generated with the maximum-parsimony algorithm. Pelagibaca bermudensis HTCC $2601^{\top}$ was used as an outgroup. Bar, 0.01 substitutions per nucleotide position. 
P. zeaxanthinifaciens $\mathrm{R}-1512^{\mathrm{T}}(94.9 \%)$. 16S rRNA gene sequence similarities between strain $\mathrm{SW}-3^{\mathrm{T}}$ and other species with validly published names within the order Rhodobacterales were $<95.7 \%$.

The DNA G + C content of strain $\mathrm{SW}-3^{\mathrm{T}}$ was estimated as described by Mesbah et al. (1989). The nucleoside mixture was separated by means of HPLC. The DNA G $+\mathrm{C}$ content of strain $\mathrm{SW}-3^{\mathrm{T}}$ was $63.7 \pm 1.0 \mathrm{~mol} \%$. Isoprenoid quinones were purified by the methods outlined in Minnikin et al. (1984) and analysed by HPLC as described by Collins (1985). The major isoprenoid quinone of strain $\mathrm{SW}-3^{\mathrm{T}}$ was Q-10.

Biomasses of strains SW- $3^{\mathrm{T}}, P$. aestuarii JCM $15119^{\mathrm{T}}, P$. homiensis KACC $11518^{\mathrm{T}}$, P. marinus NBRC $100637^{\mathrm{T}}, P$. denitrificans BCRC $12285^{\mathrm{T}}$ and P. zeaxanthinifaciens JCM $21774^{\mathrm{T}}$ were obtained after growing the strains on MA at $30{ }^{\circ} \mathrm{C}$ for 3 days under aerobic conditions. Fatty acid methyl esters were prepared, separated and identified according to the instructions for the Microbial Identification System (MIDI) (Sasser, 1990). The predominant fatty acid constituent of strain $\mathrm{SW}-3^{\mathrm{T}}$ was summed feature $8\left(\mathrm{C}_{18: 1} \omega 7 c\right.$ and/or $\left.\mathrm{C}_{18: 1} \omega 6 c ; 75.0 \%\right)$. The fatty acid profile of strain SW $-3^{\mathrm{T}}$ was similar to that of other members of the genus Paracoccus; however, there were differences in the proportions of some components (Table 1). The fatty acid profile of strain $\mathrm{SW}-3^{\mathrm{T}}$ showed a pattern distinct from $P$. denitrificans BCRC $12285^{\mathrm{T}}$. In contrast with the other five strains, $P$. denitrificans BCRC $12285^{\mathrm{T}}$ possessed fatty acids $\mathrm{C}_{11: 0} 2-\mathrm{OH}$, anteiso- $\mathrm{C}_{12: 0}$, anteiso- $\mathrm{C}_{13: 0}$ and $\mathrm{C}_{18: 1} \omega 9 c$. Furthermore, the quantity of fatty acid $\mathrm{C}_{16: 0}$ in $P$. denitrificans BCRC $12285^{\mathrm{T}}$ was relatively higher $(16.2 \%)$ and the quantity of fatty acid summed feature $8 \quad\left(\mathrm{C}_{18: 1} \omega 7 c\right.$ and/or $\left.\mathrm{C}_{18: 1} \omega 6 c\right)$ was relatively lower $(57.1 \%)$ than the other reference strains.

Polar lipids were extracted and analysed by two-dimensional TLC according to the methods of Lechevalier et al. (1977). Strain SW-3 ${ }^{\mathrm{T}}$ exhibited a complex polar lipid profile consisting of diphosphatidylglycerol (DPG), phosphatidylglycerol (PG), phosphatidylcholine (PC), an unidentified aminolipid (AL1), two unidentified glycolipids (GL1 and GL2) and four unidentified phospholipids (PL1-4) (see Supplementary Fig. S1, available in IJSEM Online). Its closest relatives, $P$. aestuarii JCM $15119^{\mathrm{T}}$, P. homiensis KACC $11518^{\mathrm{T}}$, P. marinus NBRC $100637^{\mathrm{T}}$, $P$. denitrificans BCRC $12285^{\mathrm{T}}$ and P. zeaxanthinifaciens JCM $21774^{\mathrm{T}}$, exhibited very similar polar lipid profiles all having DPG, PG, PC, unidentified aminolipid AL1 and unidentified phospholipids PL1 and PL2. However, unidentified glycolipid GL1 was present in strain SW- $3^{\mathrm{T}}$, P. homiensis KACC $11518^{\mathrm{T}}$, P. marinus NBRC $100637^{\mathrm{T}}$ and $P$. zeaxanthinifaciens JCM $21774^{\mathrm{T}}$ but was absent in $P$. aestuarii JCM $15119^{\mathrm{T}}$ and P. denitrificans BCRC $12285^{\mathrm{T}}$. Also, unidentified phospholipid PL4 was detected in strains SW $-3^{\mathrm{T}}, P$. aestuarii JCM $15119^{\mathrm{T}}, P$. homiensis KACC $11518^{\mathrm{T}}, P$. marinus NBRC $100637^{\mathrm{T}}$ and $P$. denitrificans BCRC $12285^{\mathrm{T}}$ but was not detected in P. zeaxanthinifaciens JCM $21774^{\mathrm{T}}$. Although there are some differences between the polar lipid profiles of strain $\mathrm{SW}-3^{\mathrm{T}}$ and its closest

Table 1. Cellular fatty acid composition of strain $\mathrm{SW}-3^{\top}$ and related species of the genus Paracoccus

Strains: 1 , SW- $3^{\mathrm{T}}$; 2, P. marinus NBRC $100637^{\mathrm{T}} ; 3$, P. aestuarii $\mathrm{JCM} 15119^{\mathrm{T}} ; 4$, P. homiensis $\mathrm{KACC} 11518^{\mathrm{T}}$; 5 , P. zeaxanthinifaciens $\mathrm{JCM} 21774^{\mathrm{T}}$; 6, P. denitrificans BCRC $12285^{\mathrm{T}}$. All strains were grown on MA agar at $30{ }^{\circ} \mathrm{C}$ for 3 days. Values are percentages of the total fatty acids. Fatty acids that make up $<1 \%$ of the total are not shown. For unsaturated fatty acids, the position of the double bond is located by counting from the methyl $(\omega)$ end of the carbon chain.

\begin{tabular}{|c|c|c|c|c|c|c|}
\hline Fatty acid & 1 & 2 & 3 & 4 & 5 & 6 \\
\hline $\mathrm{C}_{10: 0} 3-\mathrm{OH}$ & 4.1 & 5.2 & 8.8 & 4.1 & 7.8 & 4.3 \\
\hline $\mathrm{C}_{11: 0} 2-\mathrm{OH}$ & - & - & - & - & - & 1.1 \\
\hline $\mathrm{C}_{12: 0}$ & - & 1.6 & - & - & - & - \\
\hline anteiso- $\mathrm{C}_{12: 0}$ & - & - & - & - & - & 3.2 \\
\hline anteiso- $\mathrm{C}_{13: 0}$ & - & - & - & - & - & 1.5 \\
\hline $\mathrm{C}_{14: 0}$ & - & 1.2 & - & - & - & - \\
\hline $\mathrm{C}_{16: 0}$ & 1.5 & 4.4 & 1.8 & - & 2.1 & 16.2 \\
\hline $\mathrm{C}_{18: 0}$ & 10.2 & 7.2 & 8.6 & 4.4 & 6.0 & 4.9 \\
\hline $\mathrm{C}_{18: 0} 3-\mathrm{OH}$ & - & - & - & - & 1.9 & - \\
\hline $\mathrm{C}_{18: 1} \omega 9 c$ & - & - & - & - & - & 1.4 \\
\hline $\mathrm{C}_{18: 1} \omega 7 c$ 11-methyl & 1.1 & - & - & 5.1 & - & - \\
\hline $\mathrm{C}_{19: 0}$ cyclo $\omega 8 c$ & 3.3 & - & - & - & - & - \\
\hline \multicolumn{7}{|l|}{ Summed features ${ }^{*}$} \\
\hline 2 & - & - & 5.6 & 1.7 & 5.4 & 3.6 \\
\hline 3 & - & - & - & - & 2.8 & 1.2 \\
\hline 8 & 75.0 & 79.9 & 74.7 & 80.4 & 72.8 & 57.1 \\
\hline
\end{tabular}

${ }^{\star}$ Summed features are groups of two or three fatty acids that cannot be separated by GLC using the MIDI system. Summed feature 2 comprises $\mathrm{C}_{14: 0} 3-\mathrm{OH}$ and/or iso- $\mathrm{C}_{16: 1} \mathrm{I}$, summed feature 3 comprises $\mathrm{C}_{16: 1} \omega 7 c$ and/or $\mathrm{C}_{16: 1} \omega 6 c$ and summed feature 8 comprises $\mathrm{C}_{18: 1} \omega 7 c$ and/or $\mathrm{C}_{18: 1} \omega 6 c$. 
relatives, the similarities among them suggest they belong to the same genus.

Strain SW $-3^{\mathrm{T}}$ was examined for a broad range of phenotypic properties. Activities of catalase, oxidase, DNase and lipase and hydrolysis of starch, casein and Tweens 20, 40, 60 and 80 were determined according to standard methods (Gerhardt et al., 1994; MacFaddin, 2000). Hydrolysis of $1 \%(\mathrm{w} / \mathrm{v})$ sodium alginate was tested on MA (Hosoya et al., 2009). Hydrolysis of chitin was tested using agar medium supplemented with $0.2 \%$ colloidal chitin (Hsu \& Lockwood, 1975). The commercially available API $20 \mathrm{NE}$ and API ZYM (bioMérieux) and the MicroPlate GN2 (Biolog) microtest systems were used to determine the biochemical properties, enzyme activities and carbohydrate utilization pattern of strain SW-3 ${ }^{\mathrm{T}}$. API ZYM tests were performed according to the manufacturer's recommendation and results were read after $4 \mathrm{~h}$ of incubation at $37^{\circ} \mathrm{C}$. Because strain $\mathrm{SW}-3^{\mathrm{T}}$ required $3-5 \% \mathrm{NaCl}$ for optimal growth, for MicroPlate GN2 and API 20 NE tests, the bacterial sample was suspended in artificial seawater $(\mathrm{NaCl}$, $24 \mathrm{~g} ; \mathrm{MgCl}_{2}, 5.1 \mathrm{~g} ; \mathrm{Na}_{2} \mathrm{SO}_{4}, 4 \mathrm{~g} ; \mathrm{CaCl}_{2}, 1.1 \mathrm{~g} ; \mathrm{KCl}, 0.7 \mathrm{~g}$; $\mathrm{NaHCO}_{3}, 0.2 \mathrm{~g} ; \mathrm{KBr}, 0.1 \mathrm{~g} ; \mathrm{H}_{3} \mathrm{BO}_{3}, 0.027 \mathrm{~g} ; \mathrm{SrCl}_{2}, 0.024 \mathrm{~g}$; $\mathrm{NaF}, 0.003 \mathrm{~g}$; distilled water to 1 l; Lyman \& Fleming, 1940). The results of the API $20 \mathrm{NE}$ and MicroPlate GN2 tests were read after $72 \mathrm{~h}$ of incubation at $30^{\circ} \mathrm{C}$.
Sensitivity to antibiotics was tested by spreading cells ( 0.5 McFarland standard) on MA and using discs containing the following antibiotics ( $\mu \mathrm{g}$ per disc): ampicillin (10), chloramphenicol (30), gentamicin (10), kanamycin (30), nalidixic acid (30), novobiocin (30), penicillin $\mathrm{G}$ (10), rifampicin (5), streptomycin (10), sulphamethoxazole (23.75) plus trimethoprim (1.25) and tetracycline (30). The effects of the antibiotics on cell growth were assessed after 3 days of incubation at $30{ }^{\circ} \mathrm{C}$. The diameter of the antibiotic discs was $8 \mathrm{~mm}$. The strain was considered to be susceptible when the diameter of the inhibition zone was $>13 \mathrm{~mm}$, intermediately susceptible at $10-12 \mathrm{~mm}$ and resistant at $<10 \mathrm{~mm}$ as described by Nokhal \& Schlegel (1983).

The physiological, biochemical and morphological characteristics of strain $\mathrm{SW}-3^{\mathrm{T}}$ are given in the species description, Table 2 and Supplementary Table S1. Examination of phenotypic and genotypic characteristics revealed many common traits between the novel strain and its closest relatives, $P$. aestuarii JCM $15119^{\mathrm{T}}$, P. homiensis KACC $11518^{\mathrm{T}}$, P. marinus NBRC $100637^{\mathrm{T}}$, P. denitrificans BCRC $12285^{\mathrm{T}}$ and $P$. zeaxanthinifaciens $\mathrm{R}-1512^{\mathrm{T}}$. All strains were Gram-reaction-negative, heterotrophic, aerobic, oxidase- and catalase-positive and had a large proportion of $\mathrm{C}_{18: 1} \omega 7 \mathrm{c}$ and/or $\mathrm{C}_{18: 1} \omega 6 c$. The predominant respiratory quinone of all the strains was Q-10 and

Table 2. Differential characteristics of strain $S W-3^{\top}$ and related species of the genus Paracoccus

Strains: 1 , SW- $3^{\mathrm{T}}$; 2, P. marinus NBRC $100637^{\mathrm{T}} ; 3$, P. aestuarii JCM $15119^{\mathrm{T}}$; 4, P. homiensis KACC $11518^{\mathrm{T}} ; 5$, P. zeaxanthinifaciens JCM $21774^{\mathrm{T}}$; 6, P. denitrificans BCRC $12285^{\mathrm{T}}$. All listed characteristics were obtained in this study except for the DNA G $+\mathrm{C}$ contents of taxa 2-6, which were obtained from the following sources: Khan et al. (2008), for P. marinus KKL-A5 ${ }^{\mathrm{T}}$; Roh et al. (2009), for P. aestuarii $\mathrm{B} 7^{\mathrm{T}}$; Kim et al. (2006), for P. homiensis DD-R11 ${ }^{\mathrm{T}}$; Berry et al. (2003), for P. zeaxanthinifaciens $\mathrm{R}-1512^{\mathrm{T}}$ and Liu et al. (2008), for P. denitrificans DSM $413^{\mathrm{T}}$. + , Positive; -, negative; w, weakly positive. All strains were Gram-reaction-negative and oxidase- and catalase-positive.

\begin{tabular}{|c|c|c|c|c|c|c|}
\hline Characteristic & 1 & 2 & 3 & 4 & 5 & 6 \\
\hline Colony colour & Creamy white & Creamy white & Dull orange & Deep yellow & Deep orange & $\begin{array}{c}\text { Creamy } \\
\text { white }\end{array}$ \\
\hline $\mathrm{NaCl}$ range for growth (\%) & $0-12$ & $1-4$ & $0-4$ & $0-14$ & $3-8$ & $0-7$ \\
\hline $\mathrm{pH}$ range for growth & $7-10$ & $6-9$ & $8-10$ & $5-9$ & $6-9$ & $6-8$ \\
\hline Temperature range for growth $\left({ }^{\circ} \mathrm{C}\right)$ & $4-40$ & $10-35$ & $15-37$ & $10-40$ & $10-40$ & $10-40$ \\
\hline Arginine dihydrolase & - & + & - & - & $\mathrm{W}$ & - \\
\hline$\beta$-Galactosidase & + & - & + & + & + & - \\
\hline \multicolumn{7}{|l|}{ Hydrolysis of: } \\
\hline Gelatin & - & + & - & + & $\mathrm{W}$ & - \\
\hline Aesculin & + & - & + & + & + & - \\
\hline Tween 20 & + & - & + & - & + & - \\
\hline DNA & + & - & - & + & + & + \\
\hline \multicolumn{7}{|l|}{ Polar lipids: } \\
\hline Unidentified glycolipid GL1 & + & + & - & + & + & - \\
\hline Unidentified phospholipid PL4 & + & + & + & + & - & + \\
\hline DNA G $+C$ content $(\mathrm{mol} \%)$ & 63.7 & 69.0 & 62.0 & 63.0 & 67.6 & 66.5 \\
\hline
\end{tabular}


the DNA G $+\mathrm{C}$ contents ranged from 62 to $69 \mathrm{~mol} \%$. Strain SW $-3^{\mathrm{T}}$, however, could be clearly differentiated from these species by its ability to grow at a lower temperature (Table 2) and by its inability to utilize DL-lactic acid as a sole carbon source (Supplementary Table S1). Strain SW $-3^{\mathrm{T}}$ could also be differentiated from $P$. marinus NBRC $100637^{\mathrm{T}}$ by its cell motility, its ability to grow in higher $\mathrm{NaCl}$ concentrations and to hydrolyse Tweens 20, 40 and 80 , the presence of DNase and $\beta$-galactosidase activities, its inability to hydrolyse gelatin and the absence of arginine dihydrolase. Some features differentiated strain SW-3 $3^{\mathrm{T}}$ from $P$. aestuarii JCM $15119^{\mathrm{T}}$, including colony colour, cell motility, a higher $\mathrm{NaCl}$ range for growth, the absence of poly- $\beta$-hydroxybutyrate accumulation and the ability to hydrolyse Tweens 40 and 60 and DNA. Strain SW $-3^{\mathrm{T}}$ also presented several phenotypic characteristics that differentiated it from $P$. homiensis KACC $11518^{\mathrm{T}}$, including a difference in colony colour and the ability to hydrolyse gelatin, starch and Tweens 20, 40, 60 and 80. Other phenotypic properties distinguished strain $\mathrm{SW}-3^{\mathrm{T}}$ from $P$. zeaxanthinifaciens JCM $21774^{\mathrm{T}}$, such as a difference in colony colour, motility, a higher $\mathrm{NaCl}$ range for growth, the absence of poly- $\beta$-hydroxybutyrate accumulation, the ability to hydrolyse Tweens 40 and 60 , the inability to hydrolyse gelatin and the absence of arginine dihydrolase. In addition, strain $\mathrm{SW}-3^{\mathrm{T}}$ could be differentiated from $P$. denitrificans BCRC $12285^{\mathrm{T}}$ by its motility, its ability to grow in higher $\mathrm{NaCl}$ concentrations and hydrolyse aesculin, Tweens 20, 40, 60 and 80, the absence of poly- $\beta$-hydroxybutyrate accumulation and the presence of $\beta$-galactosidase activity.

Cells of strain SW-3 ${ }^{\mathrm{T}}$ were Gram-reaction-negative, rodshaped, mesophilic, motile by means of a single polar flagellum, catalase- and oxidase-positive and respired with oxygen as the terminal electron acceptor. Cells of strain SW$3^{\mathrm{T}}$ were able to utilize a wide variety of organic compounds as carbon and energy sources, contained Q-10 as the major quinone and summed feature $8\left(\mathrm{C}_{18: 1} \omega 7 c\right.$ and/or $\mathrm{C}_{18: 1} \omega 6 c$; $75.0 \%)$ as the predominant cellular fatty acid and contained 3-hydroxyl fatty acids with $\mathrm{C}_{10: 0} 3-\mathrm{OH}$ predominating. The DNA G $+C$ content of strain SW $-3^{\mathrm{T}}$ was $63.7 \%$ mol. These characteristics are consistent with the emended description of the genus Paracoccus (Katayama et al., 1995); however, strain $\mathrm{SW}-3^{\mathrm{T}}$ was motile and halophilic, whereas most members of the genus Paracoccus are non-motile and nonhalophilic. Only four known species of the genus Paracoccus exhibit motility, $P$. versutus, $P$. carotinifaciens, $P$. chinensis and $P$. homiensis, and, with the exception of $P$. homiensis, these species are all non-halophilic. Strain $S W-3^{T}$ and $P$. homiensis present several other phenotypic differences, as described above, therefore, strain $\mathrm{SW}-3^{\mathrm{T}}$ can be regarded as a member of the genus Paracoccus, distinct from other recognized species of the genus.

Strain SW $-3^{\mathrm{T}}$ occupied a distinct position within the genus Paracoccus, based on 16S rRNA gene sequence comparisons, and possessed a unique combination of chemotaxonomic and biochemical characteristics (Tables 1 and 2). Taken together, these results suggest that strain $\mathrm{SW}-3^{\mathrm{T}}$ represents a novel species of the genus Paracoccus, for which the name Paracoccus isoporae sp. nov. is proposed.

\section{Description of Paracoccus isoporae sp. nov.}

Paracoccus isoporae (i.so.por'ae. N.L. gen. n. isoporae of Isopora, a genus of coral, from which the strain was isolated).

Cells are Gram-reaction-negative, aerobic, rod shaped $(0.5-0.7 \times 0.7-1.5 \mu \mathrm{m})$ and motile by means of monopolar flagella. Colonies are a creamy white colour, circular and convex with entire edges and are $\sim 0.6-0.8 \mathrm{~mm}$ in diameter on MA after $48 \mathrm{~h}$ of incubation at $30{ }^{\circ} \mathrm{C}$. Growth occurs at $4-40{ }^{\circ} \mathrm{C}$ (optimum $25-30{ }^{\circ} \mathrm{C}$ ), pH 7-10 (optimum $\mathrm{pH} 9-10)$ and in $0-12 \%(\mathrm{w} / \mathrm{v}) \mathrm{NaCl}$ (optimum 3-5\%). Negative for poly- $\beta$-hydroxybutyrate granule accumulation. Positive for oxidase, catalase and DNase activities and hydrolysis of aesculin and Tweens 20, 40, 60 and 80 . Negative for lipase activity (hydrolysis of corn oil) and hydrolysis of casein, starch, alginate and chitin. In API 20 NE tests: positive for aesculin hydrolysis and $\beta$-galactosidase activity; negative for nitrate reduction, indole production, gelatin hydrolysis, D-glucose fermentation and arginine dihydrolase and urease activities. In API ZYM tests: positive for alkaline phosphatase, C4 esterase, C8 esterase lipase, C14 lipase, leucine arylamidase, valine arylamidase, acid phosphatase, naphthol-AS-BI-phosphohydrolase, $\alpha$ - and $\beta$-galactosidase, $\alpha$ - and $\beta$-glucosidase, $\alpha$ mannosidase and $\alpha$-fucosidase activities; negative for cystine arylamidase, trypsin, $\alpha$-chymotrypsin, $\beta$-glucouronidase and $N$-acetyl- $\beta$-glucosaminidase activities. The following compounds are utilized as sole carbon sources in the GN2 microplate: dextrin, Tweens 40 and 80, Lfucose, D-galactose, gentiobiose, $\alpha$-D-glucose, $\alpha$-lactose, lactulose, maltose, D-mannitol, sucrose, trehalose, turanose, pyruvic acid methyl ester, succinic acid monomethyl ester, $\alpha-, \beta$ and $\gamma$-hydroxybutyric acid, 2,3-butanediol and glycerol. All other substrates in the GN2 microplate are not utilized. Sensitive to rifampicin, nalidixic acid, kanamycin, chloramphenicol, gentamicin, novobiocin, streptomycin, tetracycline, ampicillin, penicillin $G$ and sulphamethoxazole plus trimethoprim. The predominant cellular fatty acid is summed feature $8\left(\mathrm{C}_{18: 1} \omega 7 c\right.$ and/or $\left.\mathrm{C}_{18: 1} \omega 6 c\right)$. The major respiratory quinone is $\mathrm{Q}-10$. The polar lipids are DPG, PG, PC, an unidentified aminolipid (AL1), two unidentified glycolipids (GL1 and GL2) and four unidentified phospholipids (PL1-4).

The type strain, SW $-3^{\mathrm{T}}\left(=\mathrm{LMG} 25205^{\mathrm{T}}=\mathrm{BCRC} 17967^{\mathrm{T}}\right.$ ), was isolated from a reef-building coral, Isopora palifera, collected off the coast of Southern Taiwan. The DNA G + C content of the type strain is $63.7 \mathrm{~mol} \%$.

\section{Acknowledgements}

This study was funded by grants from the Academia Sinica (Thematic Grant 20082010), Taipei, Taiwan, Republic of China.

\section{References}

Berry, A., Janssens, D., Hümbelin, M., Jore, J. P. M., Hoste, B., Cleenwerck, I., Vancanneyt, M., Bretzel, W., Mayer, A. F. \& other 
authors (2003). Paracoccus zeaxanthinifaciens sp. nov., a zeaxanthinproducing bacterium. Int J Syst Evol Microbiol 53, 231-238.

Chen, W. M., Laevens, S., Lee, T. M., Coenye, T., De Vos, P., Mergeay, M. \& Vandamme, P. (2001). Ralstonia taiwanensis sp. nov., isolated from root nodules of Mimosa species and sputum of a cystic fibrosis patient. Int J Syst Evol Microbiol 51, 1729-1735.

Chun, J., Lee, J.-H., Jung, Y., Kim, M., Kim, S., Kim, B. K. \& Lim, Y. W. (2007). EzTaxon: a web-based tool for the identification of prokaryotes based on $16 \mathrm{~S}$ ribosomal RNA gene sequences. Int J Syst Evol Microbiol 57, 2259-2261.

Collins, M. D. (1985). Analysis of isoprenoid quinones. Methods Microbiol 18, 329-366.

Daneshvar, M. I., Hollis, D. G., Weyant, R. S., Steigerwalt, A. G., Whitney, A. M., Douglas, M. P., Macgregor, J. P., Jordan, J. G., Mayer, L. W. \& other authors (2003). Paracoccus yeeii sp. nov. (formerly CDC group EO-2), a novel bacterial species associated with human infection. J Clin Microbiol 41, 1289-1294.

Davis, D. H., Doudoroff, M., Stanier, R. Y. \& Mandel, M. (1969). Proposal to reject the genus Hydrogenomonas: taxonomic implications. Int J Syst Bacteriol 19, 375-390.

Deng, Z. S., Zhao, L. F., Xu, L., Kong, Z. Y., Zhao, P., Qin, W., Chang, J. L. \& Wei, G. H. (2010). Paracoccus sphaerophysae sp. nov., a siderophore-producing, endophytic bacterium isolated from root nodules of Sphaerophysa salsula. Int J Syst Evol Microbiol 61, 665-669.

Felsenstein, J. (1981). Evolutionary trees from DNA sequences: a maximum likelihood approach. J Mol Evol 17, 368-376.

Felsenstein, J. (1993). PHYLIP (phylogeny inference package), version 3.5c. Distributed by the author. Department of Genome Sciences, University of Washington, Seattle, USA.

Gerhardt, P., Murray, R. G. E., Wood, W. A. \& Krieg, N. R. (editors) (1994). Methods for General and Molecular Bacteriology. Washington, DC: American Society for Microbiology.

Hall, T. A. (1999). BioEdit: a user-friendly biological sequence alignment editor and analysis program for Windows 95/98/NT. Nucleic Acids Symp Ser 41, 95-98.

Hosoya, S., Adachi, K. \& Kasai, H. (2009). Thalassomonas actiniarum sp. nov. and Thalassomonas haliotis sp. nov., isolated from marine animals. Int J Syst Evol Microbiol 59, 686-690.

Hsu, S. C. \& Lockwood, J. L. (1975). Powdered chitin agar as a selective medium for enumeration of actinomycetes in water and soil. Appl Microbiol 29, 422-426.

Katayama, Y., Hiraishi, A. \& Kuraishi, H. (1995). Paracoccus thiocyanatus sp. nov., a new species of thiocyanate-utilizing facultative chemolithotroph, and transfer of Thiobacillus versutus to the genus Paracoccus as Paracoccus versutus comb. nov. with emendation of the genus. Microbiology 141, 1469-1477.

Khan, S. T., Takaichi, S. \& Harayama, S. (2008). Paracoccus marinus sp. nov., an adonixanthin diglucoside-producing bacterium isolated from coastal seawater in Tokyo Bay. Int J Syst Evol Microbiol 58, 383386.

Kim, B. Y., Weon, H. Y., Yoo, S. H., Kwon, S. W., Cho, Y. H., Stackebrandt, E. \& Go, S. J. (2006). Paracoccus homiensis sp. nov., isolated from a sea-sand sample. Int J Syst Evol Microbiol 56, 23872390.

Kim, Y. O., Kong, H. J., Park, S., Kang, S. J., Kim, K. K., Moon, D. Y., Oh, T. K. \& Yoon, J. H. (2010). Paracoccus fistulariae sp. nov., a lipolytic bacterium isolated from bluespotted cornetfish Fistularia commeronii. Int J Syst Evol Microbiol 60, 2908-2912.

Kimura, M. (1983). The Neutral Theory of Molecular Evolution. Cambridge: Cambridge University Press.
Kluge, A. G. \& Farris, F. S. (1969). Quantitative phyletics and the evolution of anurans. Syst Zool 18, 1-32.

Kumar, S., Tamura, K. \& Nei, M. (2004). MEGA3: integrated software for molecular evolutionary genetics analysis and sequence alignment. Brief Bioinform 5, 150-163.

La, H. J., Im, W.-T., Ten, L. N., Kang, M. S., Shin, D. Y. \& Lee, S. T. (2005). Paracoccus koreensis sp. nov., isolated from anaerobic granules in an upflow anaerobic sludge blanket (UASB) reactor. Int J Syst Evol Microbiol 55, 1657-1660.

Lechevalier, M. P., de Bikvre, C. \& Lechevalier, H. A. (1977). Chemotaxonomy of aerobic actinomycetes: phospholipid composition. Biochem Syst Ecol 5, 249-260.

Liu, X.-Y., Wang, B.-J., Jiang, C.-Y. \& Liu, S.-J. (2006). Paracoccus sulfuroxidans sp. nov., a sulfur oxidizer from activated sludge. Int $J$ Syst Evol Microbiol 56, 2693-2695.

Liu, Z.-P., Wang, B.-J., Liu, X.-Y., Dai, X., Liu, Y.-H. \& Liu, S.-J. (2008). Paracoccus halophilus sp. nov., isolated from marine sediment of the South China Sea, China, and emended description of genus Paracoccus Davis 1969. Int J Syst Evol Microbiol 58, 257-261.

Lyman, J. \& Fleming, R. H. (1940). Composition of sea water. J Mar Res 3, 134-146.

MacFaddin, J. F. (2000). Biochemical Tests for the Identification of Medical Bacteria, 3rd edn. Baltimore, MD: Williams \& Wilkins.

Maidak, B. L., Cole, J. R., Lilburn, T. G., Parker, C. T., Jr, Saxman, P. R., Farris, R. J., Garrity, G. M., Olsen, G. J., Schmidt, T. M. \& Tiedje, J. M. (2001). The RDP-II (Ribosomal Database Project). Nucleic Acids Res 29, 173-174.

Mesbah, M., Premachandran, U. \& Whitman, W. B. (1989). Precise measurement of the $\mathrm{G}+\mathrm{C}$ content of deoxyribonucleic acid by highperformance liquid chromatography. Int J Syst Bacteriol 39, 159-167.

Minnikin, D. E., O'Donnell, A. G., Goodfellow, M., Alderson, G., Athalye, M., Schaal, K. \& Parlett, J. H. (1984). An integrated procedure for the extraction of bacterial isoprenoid quinones and polar lipids. J Microbiol Methods 2, 233-241.

Nokhal, T. H. \& Schlegel, H. G. (1983). Taxonomic study of Paracoccus denitrificans. Int J Syst Bacteriol 33, 26-37.

Powers, E. M. (1995). Efficacy of the Ryu nonstaining KOH technique for rapidly determining Gram reactions of food-borne and waterborne bacteria and yeasts. Appl Environ Microbiol 61, 3756-3758.

Roh, S. W., Nam, Y. D., Chang, H. W., Kim, K. H., Kim, M. S., Shin, K. S., Yoon, J. H., Oh, H. M. \& Bae, J. W. (2009). Paracoccus aestuarii sp. nov., isolated from tidal flat sediment. Int J Syst Evol Microbiol 59, 790-794.

Saitou, N. \& Nei, M. (1987). The neighbor-joining method: a new method for reconstructing phylogenetic trees. Mol Biol Evol 4, 406-425.

Sasser, M. (1990). Identification of bacteria by gas chromatography of cellular fatty acids, MIDI Technical Note 101. Newark, DE: MIDI Inc.

Siller, H., Rainey, F. A., Stackebrandt, E. \& Winter, J. (1996). Isolation and characterization of a new Gram-negative, acetone-degrading, nitrate-reducing bacterium from soil, Paracoccus solventivorans sp. nov. Int J Syst Bacteriol 46, 1125-1130.

Thompson, J. D., Gibson, T. J., Plewniak, F., Jeanmougin, F. \& Higgins, D. G. (1997). The CLUSTAL_X windows interface: flexible strategies for multiple sequence alignment aided by quality analysis tools. Nucleic Acids Res 25, 4876-4882.

Tsubokura, A., Yoneda, H. \& Mizuta, H. (1999). Paracoccus carotinifaciens sp. nov., a new aerobic Gram-negative astaxanthinproducing bacterium. Int J Syst Bacteriol 49, 277-282.

Wallet, F., Blondiaux, N., Foy, C. L., Loïez, C., Armand, S., Pagniez, D. \& Courcol, R. J. (2010). Paracoccus yeei: a new unusual opportunistic bacterium in ambulatory peritoneal dialysis. Int J Infect Dis 14, e173e174. 